\title{
How Did Money Market Fund Perform In Its Earlier Years Of Inception In Developing Economies: A Case Of Kenya Fund Market
}

\section{Mohamed Shano Dawe}

Meru University of science and technology, Kenya mohamedsdawe@gmail.com

\begin{abstract}
This research evaluates the performance of money market fund in Kenya for the period 2005 to 2009. The choice of the period was to demonstrate how the fund has been performing in early years when the product was perceived to be new in Kenya and Africa at large. The objective of the study was to compare performance of different funds. This research was motivated by the fact that there was hardly any research on money market funds carried out in less developed economies. The target population was all money market funds in Kenya. The research mainly used secondary data on daily returns and annual reports for the period 2005 to 2009 so as to calculate the net asset value and hence the performance evaluation models proposed by Sharpe (1966), Jensen (1968) and Treynor and Mazuy (1966). In order to establish consistency of performance over the research period using different performance models, a normality test was carried out using Koglomorov-Smirnov and Q-Q plot to establish whether parametric or non-parametric test were to be used. However, as the population was small, Kendall tau-b was used. Over the research period, the finding was that the funds did not perform better than the market on a risk- adjusted basis using various performance measures.
\end{abstract}

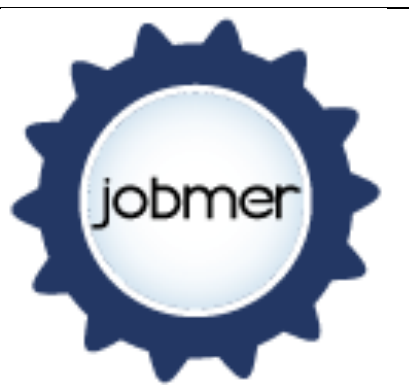

Journal of Business

Management and Economic Research Vol.2, Issue.2, 2018 pp. 35-43

Doi: 10.29226/TR1001.2018.19

Keywords: Money market fund, Risk adjusted returns, Net asset values, performance 


\section{INTRODUCTION}

Investment in financial assets like money market fund was new phenomena in developing countries, Kenya included. Lately, there has been proliferation of many financial products in Kenya financial markets. The investors should understand how the money market has been performing in the past, around the time the trading of such products was adopted.

In order to make optimal investment, history of past performance is also important. The performance of money market fund in its early years is also pertinent to researchers as a way of demonstrating where the started from.

According to Johnstone and Carnes (2010), several potential problems may arise for individual investors in their pursuit to invest, namely; limited knowledge of stock and bonds, limited amount of investable funds making the investor to purchase few issues and each subsequent investment may require revaluations of holding to ensure an appropriate mix. In order to counter such problems, an investment company offers viable solutions through advisory services on financial assets.

For money market funds to perform, professional fund managers should be able to earn above average returns through successful securities analysis. Most of the time, fund managers face challenges to pick mispriced securities into the portfolio in order to earn excess return for the investors. The excess return is earned when the individual portfolio has higher than that of the aggregate which acts as a benchmark. Money market and income securities are intended for the stability of the capital. It is invested in treasury bills and is ideal for investors with a short-term horizon.

Generally, worldwide funds industry grew significantly during 1990s due to a shift by individual investors from real estate and tangible assets to financial assets, increase of such investors to preferences to indirect ownership of stock and bonds through mutual funds and the growth of tax deferred investing for retirement through pension plans which were used to own mutual funds (Fabbozi, Modigliani, Jones \& Ferri, 2002)

For example, the number of funds grew substantially in the United States of America (USA) from 1980s. At the end of 2005, the combined assets of U.S. funds approached $\$ 9$ trillion, up from $\$ 370$ billion in 1984, while the number of individual funds grew from 1,200 to almost 9,000 over the same period (Bliss, Potter \& Schwarz, 2008). This reflected increased levels of sophistications of investors in terms of their knowledge of and appreciation of alternatives to commercial bank services (Johnstone et al, 2010).

In Kenya however, this industry did not take off as early as in developed countries. According to Capital market authority (CMA) investor education handbook (2010), there were only eight funds as at 2010 which were in operation and making necessary reporting, having an average value of Ksh.17.6 billion. These funds included African Alliance, Old Mutual, British American, Stanbic, Commercial Bank of Africa, Zimele, Suntra and Insurance Companies of East Africa (ICEA). This number grew significantly from virtually zero in 2001 to 11 in 2008 while the asset portfolio had grown by an average of ksh.1.9 billion annually to ksh.17.6 billion in the past 9 years to the year 2010 .

The evidence of fund performance in those early years was numerous. However, almost all the researches were carried out in developed markets. Miller, Panther and Mazunder (2008) on cross 
autocorrelations among asset classes in USA mutual funds; Huhmann and Bhattacharyya (2005) on whether USA funds advertising provide the necessary investment information; Ramasamy and Yeung (2003) on funds in emerging markets by looking at Malaysia; Kothari (2001) on mutual funds' performance in New York stock exchange; Thanou (2008) on funds evaluations during up and down market conditions in Greek equity mutual funds.

With no much study on funds' performance in Kenya in the past, investors may not be fully informed in order to make rational investment decision making their effort vainness. It is therefore important from the onset to establish criteria which can be used by investors base their choice depending on their risk profile over their investment horizon. This research therefore shed some light on how the money market performed in the past.

This research used the theory of Portfolio optimizations that involve the selection of securities to be included in the portfolio and the determination of portfolio funds in each security (Jones, 2004). Harry Markowitz (1952) developed the theory of portfolio analysis that provides the basis for scientific portfolio construction that result in efficient portfolio. He examined the problem of finding the portfolio with the maximum expected return for a given level of risk. That is, using the combinations of risk and returns of the portfolio to predict efficient and inefficient portfolios (Varian, 1993). The goal of portfolio managers should therefore be to minimize portfolio risk for any levels of expected returns (Bhalla, 2002). His tasks therefore were to translate security performance to portfolio performance and to select efficient portfolios among large numbers that were available. The task of the individual investor was to select desirable portfolio from efficient ones based on his risk profile (Varian, 1993). The lesson drawn from this theory is that different funds have different degrees of risks and returns due to intentional or unintentional predictions. In addition, holding mispriced securities or undiversified portfolio could lead to poor performance. Therefore, Alpha, beta and $\mathrm{R}$ squared that were used in performance evaluation were derived from Markowitz theory of portfolio construction.

The empirical findings on fund performance are mixed. Gruber (1996) finds using a four-factor model that a fund underperforms by 65 basis points per year. Since the average expense ratio in his sample is about 113 basis points per year, this implies that funds earn positive risk-adjusted returns, but charge the investors more than the value added. Wermers (2000) on his part carried out a research on funds' performance in America and found that funds hold stocks that outperform by market 1.3 percent per year, but their net results underperform by one percent. Out of this, 1.6 percent is due to expense and transaction costs. Taib and Isa (2007) also carried out research on Malaysian funds aggregate performance over the period 1991-2001 by employing different performance measures. Their results show that on average, the performance falls below market portfolio and risk free returns. Arugaslan, Edwards \& Samant (2008) used 50 US based international funds to evaluate their Risk-adjusted performance during1994-2004.Their empirical results show that the funds with the highest average returns may lose their attractiveness to investors once the degree of risk embedded in the fund has been factored into the analysis.

As evident from the empirical researches drawn from developed economies, the result gave mixed findings. Some give positive results while others gave negative results. The study explored on funds in Kenya as a developing economy with unique characteristics different from those of developed nations so as to establish whether the findings in developed nations can be replicated. 
Mohamed Shano Dawe, 2018, Vol.2, Issue.2, pp.35-43

\section{METHODS}

The study employed descriptive cross sectional and longitudinal research design. The data collected was quantitative in nature and were collected from each fund. The research used mainly secondary data obtained from funds data base and annual reports requested from fund managers. The population of the study constituted all the funds in Kenya between $1^{\text {st }}$ January 2006 and $31^{\text {st }}$ December 2009. The monthly returns for each scheme were calculated from the daily net asset value (NAV) of each fund. The daily NAV was then used to calculate the monthly and yearly returns for individual funds and that of the market over the study period.

In order to increase reliability for the secondary data, the data was obtained from the funds data base and annual reports which were certified. The content in these sources are heavily regulated according to law and are therefore considered to be reliable. To test the validity of secondary data, Karlsson and persson (2005) argue that the quantitative empirical study requires a long observation period and the inclusion of as many funds as possible in the study. They chose five-year study and included many funds as possible. This research also chose a four-year study and included all the funds that were in existence from 2006 to 2009 so as to reduce survivorship bias. In order to increase the validity, the net asset values were calculated from monthly data.

The analyst from Old Mutual was then used to gather data from the target population. The monthly data pertaining to the unit trust performance covering the period from $1^{\text {st }}$ January 2006 to 31 $1^{\text {st }}$ December 2009 was collected from the funds data base and annual reports which were available in the business daily newspapers and in some cases from fund managers themselves. In order to determine which model to use, the funds normality were tested. According to Razali and Wah (2010) the normal quartile-quartile (Q-Q) plots is the most commonly used and effective diagnostic tool for checking the normality of the data. The fund returns were therefore tested for normality using Kolmogorov-Smirnov test and Q-Q plots. Kolmogorov-Smirnov test is appropriate in a situation where the parameters of hypothesized distribution are completely known (Razali et al, 2010). As the data on funds were found to be normal, measures using capital asset pricing model were ideal. Therefore the standard performance measures developed by Sharpe (1966),Treynor (1965) and Jensen (1967) were used to measure performance

\section{Performance of Money Market Funds}

During the year 2005, there were only three mutual funds, which were trading in money market namely; Old Mutual, Britak and African Alliance. The number grew to seven funds by 2009. All the funds in 2005 earned higher returns than the market index. However, in 2006, all the funds had negative returns except OMK which had a slightly higher return of $0.45 \%$ compared to the market index of $3.1 \%$. In 2007, all the funds managed to earn higher positive returns compared to the market except African Alliance which had a negative return of $0.4 \%$ against a positive market return of $0.2 \%$. Again, in 2008, the funds earned a higher positive returns than the market against Britak which had a negative return of $0.03 \%$ against a negative market return of $3.2 \%$. The market return for 2009 was also negative while the individual funds had positive returns except Zimele, Suntra and ICEA. Generally, OMK had consistent positive returns over the research period. These summaries of returns and risk as measured in standard deviation and beta for all the funds were provided in Table 1 below. 
Mohamed Shano Dawe, 2018, Vol.2, Issue.2, pp.35-43

Table 1: Returns and Risk (RP $\delta P$ and $\beta P$ ) for the Money Market

\begin{tabular}{|c|c|c|c|c|c|c|c|c|c|c|c|c|}
\hline \multirow{2}{*}{$\begin{array}{l}\text { Funds } \\
\text { name }\end{array}$} & \multicolumn{5}{|c|}{2006} & \multicolumn{3}{|l|}{2007} & \multicolumn{3}{|l|}{2008} & \multirow{2}{*}{$\begin{array}{c}2009 \\
\mathbf{R}^{2}\end{array}$} \\
\hline & $\mathbf{R}_{\mathbf{P}}$ & $\delta_{\mathrm{P}}$ & $\beta_{\mathrm{P}}$ & $\mathbf{R}^{2}$ & $\mathbf{R}_{\mathbf{P}}$ & $\delta_{P}$ & $\beta_{\mathrm{P}}$ & $\mathbf{R}^{2}$ & $\mathbf{R P}_{\mathbf{P}}$ & $\delta_{\mathrm{P}}$ & $\beta_{\mathrm{P}}$ & \\
\hline OMK & 0.0045 & 0.1585 & -1.389 & 0.0100 & 0.0683 & 0.0969 & 0.0139 & 0.1059 & 0.0843 & 0.0115 & 0.0760 & -0.3623 \\
\hline BRITAK & -0.0180 & 0.0616 & 0.2561 & 0.0071 & 0.0682 & -0.3975 & -0.0004 & 0.0183 & -0.0457 & 0.0353 & 0.1158 & -0.1364 \\
\hline African & -0.0182 & 0.0498 & -0.2343 & -0.004 & 0.0227 & 0.0889 & 0.0090 & 0.0556 & -0.3111 & 0.0110 & 0.0351 & -0.0419 \\
\hline Stanbic & -0.1868 & 0.3439 & 5.4921 & 0.0168 & 0.0644 & 0.0385 & 0.0106 & 0.0557 & -0.1838 & 0.0261 & 0.0839 & 0.0054 \\
\hline CBA & -0.045 & 0.1128 & 0.1870 & 0.0282 & 0.1750 & 1.5213 & 0.0058 & 0.0661 & 0.3303 & 0.0113 & 0.1215 & 0.1703 \\
\hline Zimele & & & & 0.0169 & 0.1860 & 3.8046 & 0.0199 & 0.0661 & 0.2581 & -0.002 & 0.0062 & 0.0186 \\
\hline Suntra & & & & & & & 0.0123 & 0.0953 & -0.6536 & -0.002 & 0.0953 & -0.3071 \\
\hline ICEA & & & & & & & 0.0386 & 0.0755 & -0.1640 & -0.009 & 0.0556 & 0.0452 \\
\hline Market & 0.0306 & 0.042 & & 0.002 & 0.039 & & -0.0322 & 0.0816 & & -0.002 & 0.0947 & \\
\hline
\end{tabular}

During the year 2005, all the funds were more risky than the market as measured by standard deviation. The risk of the market was $5.1 \%$ while OMK was the most risky with $17.38 \%$. African Alliance had the least risk of $9.4 \%$. In 2006, again the market was less risky with $4.2 \%$ while the least risky fund was still African Alliace with $4.98 \%$ and the most risky fund was Stanbic with 34.3\%. African Alliance was less risky with 2.26\% in 2007 against the market risk of 3.9\%. However, Zimele was the riskiest with a standard deviation of $18.6 \%$ closely followed by CBA with a standard deviation of $17.5 \%$. In 2008 , Britak was the safest with $1.8 \%$ against the market risk of $8 \%$. The most risky fund was OMK with a standard deviation of $10.6 \%$.

All the funds are less risky as compared to the market except Suntra with 9.5\% and OMK with (10.6\%). In 2009, all the funds were less risky than the market except CBA (12.2\%), Britak (11.6\%) and Suntra (9.5\%) against market risk of $9.4 \%$. Zimele was the safest with a risk of $0.6 \%$ followed by African Alliance with 3.5\%. Generally, African Alliance was relatively the safest security for investment during the study period.

The aggressiveness or volatility of the fund is measured by use of beta coefficient. Beta measures the systematic risk of the fund. African Alliance was the most aggressive fund during 2005 with a coefficient of 1.29. During 2006, Stanbic was most aggressive with a beta of 5.49 followed by Zimele with a beta of 3.8 and then by CBA with a beta of 1.52. In 2007, Zimele was most aggressive with a beta of 3.8 followed by CBA with a beta of 1.5. During the year 2008 and 2009, none of the funds was aggressive as all had a beta of less than one. 
Table 2 below shows year-to-year risk adjusted Sharpe, Treynor and Jensen performance measures. Sharpe gives reward to variability ratio. All the funds including the market return had negative returns in 2005. However, in 2006, all the individual funds had negative returns while the market had a positive return of 0.73. In 2007, 2008 and 2009, all the funds including the market portfolio had negative returns. Despite negative returns, all the funds underperformed the market during the period of study.

Table 2: Sharpe, Treynor and Jensen Measures of Performance for Money Market Fund

\begin{tabular}{|c|c|c|c|c|c|c|c|c|c|c|c|c|}
\hline \multirow{2}{*}{$\begin{array}{l}\text { Funds } \\
\text { name }\end{array}$} & \multicolumn{3}{|c|}{2006} & \multicolumn{3}{|c|}{2007} & \multicolumn{3}{|c|}{2008} & \multicolumn{3}{|c|}{2009} \\
\hline & $P$ & $P$ & A & $P$ & $P$ & A & $P$ & $P$ & A & $P$ & $P$ & A \\
\hline OMK & -0.401 & 0.046 & -0.116 & -0.849 & -0.598 & -0.051 & -0.577 & -0.7249 & -0.052 & -0.821 & 0.1724 & -0.09 \\
\hline BRITAK & -1.400 & -0.337 & -0.077 & -0.892 & 0.153 & -0.089 & -4.115 & 1.6508 & -0.080 & -0.334 & 0.284 & -0.05 \\
\hline African & -1.73 & 0.369 & -0.095 & -3.178 & -0.81 & -0.066 & -1.188 & 0.2122 & -0.099 & -1.795 & 1.5026 & -0.066 \\
\hline Stanbic & -0.741 & -0.046 & -0.049 & -0.794 & -1.329 & -0.049 & -1.1572 & 0.3507 & -0.084 & -0.572 & -8.930 & -0.048 \\
\hline CBA & -1.003 & -0.605 & -0.106 & -0.227 & -0.026 & 0.0670 & -1.0468 & -0.2094 & -0.034 & -0.516 & -0.368 & -0.05 \\
\hline Zimele & & & & -0.274 & -0.013 & 0.2162 & -0.8326 & -0.2133 & -0.027 & -12.3 & -4.086 & -0.075 \\
\hline Suntra & & & & & & & 0.6578 & 0.0959 & -0.133 & -0.797 & 0.2472 & -0.099 \\
\hline ICEA & & & & & & & -0.4786 & 0.2203 & -0.054 & -1.497 & -1.84 & -0.08 \\
\hline
\end{tabular}

Treynor performance measure also gives the same result Sharpe measure except that it uses Beta as a measure of risk. Similarly, none of the fund outperformed the market according to Treynor measure.

On average, the Jensen alpha should equal zero, which implies that the return is commensurate with the underlying risk. A positive alpha implies that excess return is attained for value, while a negative value reflects underperformance by that amount (Traynor, 2010). The result shows that in 2005, all the funds outperformed the market. However, in 2006, none of the funds outperformed the market. In 2007, only Zimele and CBA outperformed the market but in 2008 and 2009, none of the funds had outperformed the market. Generally, the funds did poorly as compared to the market during the study period.

\section{DISCUSSION, CONCLUSION AND SUGGESTIONS}

On average, all the funds during the study periods performed poorly against the market index. The inferior risk adjusted performance measures was in agreement with findings by Taib and Isa (2007) who studied Malaysian funds aggregate performance. A mixed finding was made in the studies by Mehreen \& Nawazish ( 2011) that show the funds outperformed the market as revealed by Jensen alpha while Sharpe shows that no funds were preferable. According to them, Mutual Fund 
industry's Sharpe ratio is 0.47 as compared to market that is 0.27 risk premium per one percent of standard deviation. Results of Jensen differential measure also show positive after cost alpha. Hence, overall results suggest that funds in Pakistan are able to add value. Whereas results also show some of the funds under perform, these funds are facing the diversification problem. According to them, funds industry outperformed the market proxy by 0.86 percent.

However a different finding was made in the study by Lai and Lau (2010) who examined the performance of 311 mutual funds from January 1990 to December 2005 in Malaysia by using composite portfolio performance measures and found evidence that fund performances yield superior returns with relatively lower systematic risks.

African alliance was the most aggressive fund in the money market as shown by positive betas. Both the equity and blended were generally aggressive in 2006 and 2007 even though they had negative betas in subsequent years. The funds generally have lower standard deviation implying that all the portfolios are well diversified. It was noted that young and small firms perform better than big and old firms which is in consistent with the study by Karoui and Meier (2009) who used different model and found that newly launched funds outperform their counterparts significantly using Carhart four factor models. This is because newly launched funds are afforded greater autonomy in portfolio choice because they have a smaller base of investor capital to allocate to individual securities.

Generally, none of the funds outperformed the market index as almost all the funds had negative Sharpe and Jensen alphas for the sample period. However, treynor index were positive for some funds and negative for others in money market funds and therefore neither underperforms nor outperforms the market.

The objective of the research was to measure the performance of money market funds in Kenya. For the five-year period, the funds performed no better than the market on a risk- adjusted basis using various performance measures. The funds were neither preferable nor outperform the market. Further, there were no portfolio diversifications as shown by lower coefficient of determination. However, the individual funds risks were generally lower compared to that of the market as measured using standard deviations and beta. This was consistent with many other empirical findings.

The study suggest research to be carried out on the effect of recent government regulation of funds on its performance, the impact of outreach activities by the funds on its performance and the adoption of county government on the performance of in Kenya

\section{REFERENCES}

Arugaslan, O., Edwards, E., \& Samant, A. (2008). Evaluating large US-based equity mutual funds using risk-adjusted performance measures. International Journal of Commerce and Management, 17(1/2), 6-24. Doi: 10.1108/10569210710774721

Bhalla, V.K (2002). Portfolio analysis and management.Chand\&Company ltd, New Delhi

Baquero, G., Horst, J. \& Verbeek, M. (2005). Survival, look-ahead bias and the Persistence in hedge fund performance. Journal of Financial and Quantitative Analysis, 40(3), 493-517. 
Bliss, R. T., Potter, M. E.\& Schwarz, C. (2008).Performance Characteristics of Individually-Managed versus Team-Managed Mutual Funds. Journal of Portfolio Management, 34(3), 110-119.

CMA (2010), Investors handbook, Kenya

Gruber, M.J., (1996). Another puzzle: the growth in actively managed mutual funds. Journal of Finance, 51,783-810.

Halla V.K (2005). Investment Management: Security Analysis and Portfolio Management $12^{\text {th }}$ Edition, S. Chand and Company New Delhi.

Jensen, Michael C., (1967). The performance of Mutual funds in the period 1945-64. Journal of Finance 23, 389-416.

Jensen, M. (1968). Risk, the pricing of capital assets, and the evaluation of investment

Portfolios. Journal of Business 42, 167-247.

Jensen, M. \& Meckling, W. (1976). “Theory of the firm: managerial behavior, agency costs

And ownership structure". Journal of Financial Economics, 3,305-60.

Johnston, K., Hatem, J., \& Carnes, T. A. (2010). Investor education: how plan sponsors

should report your returns. Managerial Finance, 36(4), 354-363. Doi: 10.1108/03074351011027547

Jones, C. P. (2004). Investments: Analysis and Management. (9th ed.). New Delhi: John Wiley \&Sons.

Ippolito, R.A. (1989). "Efficiency with costly information: a study of mutual fund performance, 1965-1984". The Quarterly Journal of Economics, 104, 1-23.

Kahn,R.N \& Rudd, A.,(1995). Does Historical Performance Predict Future Performance? Financial Analysts Journal, 51(6), 43-52.

Karlsson,T \& Persson M.,(2005).Mutual Fund Performance. Unpublished theses, Goteborg University,Sweden.

Kohn, M. G. (2009). Financial Institutions and Markets. McGraw-Hill, Ryerson, Limited.

Kothari, S.P \& Warner,J.B (2001) . Evaluating mutual fund performance. The Journal of Finance, LVI, 5

Markowitz, H. (1952). "Portfolio Selection". Journal of Finance, 7, 77-91.

Meier, I. and Karoui, A. (2009). Mutual Fund Tournaments. Australasian Finance and Banking Conference, 2009. Available at SSRN: http://ssrn.com/abstract $=1459647$

Miller, E. M., Prather, L. J. \& Mazumder, M. I. (2008). Cross-autocorrelations among asset classes: Evidence from the mutual fund industry. Managerial Finance, 34(11), 756-771. Doi: $10.1108 / 03074350810900488$

Razali,N.M \& Wah ,Y.B .(2010). Power comparisons of some selected normality tests.

Proceedings of the Regional Conference on Statistical Sciences,ISBN 978-967-363-157-5

Taib, F. \& Isa, M. (2007).Malaysian unit trust aggregate performance. Journals of Managerial Finance, $33,102-121$. 
Thanou, E. (2008). Mutual Fund Evaluation During Up and Down Market Conditions: The Case of Greek Equity Mutual Funds. International Research Journal of Finance and Economics, 13, pp. 84-93.

The Kenya gazette (April 2010). Republic of Kenya gazette notice, No.4770, Volume CXII

No.45.

Treynor, J.L. \& Mazuy, K. (1966). “Can mutual funds outguess the market? .Harvard

Business Review, Vol. 44 No. 4, pp. 131-6.

Varian, H. (1993). "A Portfolio of Nobel Laureates: Markowitz, Miller and Sharpe." Journal of Economic Perspectives, 7(1): 159-169

Wermers, R. (2000). "Mutual fund performance: an empirical decomposition into stock-picking talent, style, transaction costs, and expenses". The Journal of Finance, 55, 1655-95. 